\title{
SOBRE O ÚTIL E O HONESTO EM MONTAIGNE: ENTRE O ESTOICISMO E A RAZÃO DE ESTADO ${ }^{1}$
}

Taynam Santos Luz Bueno (USP) ${ }^{2}$

taynambueno@hotmail.com

Resumo: Este trabalho se propõe a analisar o primeiro texto do terceiro livro dos Ensaios de Montaigne, intitulado "Do útil e do honesto", estabelecendo um paralelo entre as ideias de Montaigne com, em primeiro plano, as construções do moralismo estoico bem como, com os preceitos desenvolvidos por Maquiavel. Com isso, pretendemos evidenciar que, no contexto político de sua época, Montaigne afirma a ideia de fides como elemento capaz de garantir a manutenção e a conservação das instituições políticas de modo mais eficaz que a simples ética de resultados professada pelos defensores dos argumentos da razão de Estado, unindo, portanto, tanto a moral estoica, quanto as correntes de pensamento de seu tempo.

Palavras-chave: Montaigne; Cícero; Fides; Moral Estoica.

Explicamos mal a honestidade e a beleza de uma ação por meio de sua utilidade; e concluímos mal ao estimar que todos estejam obrigados ela e que ela seja honesta para todos se for útil. Montaigne, Ensaios

$(I I I, 1)$

\section{INTRODUÇÃO}

O texto que abre o terceiro volume dos Ensaios de Mon-

\footnotetext{
${ }^{1}$ Recebido: 02-11-2016/ Aceito: 26-02-2017/ Publicado on-line: 31-07-2017.

2 Taynam Santos Luz Bueno é doutoranda do Depto. de Filosofia da Universidade de São Paulo, São Paulo, SP, Brasil.
} 
taigne parece ser, segundo Villey ${ }^{3}$, datado do início do ano de 1586. Tal período, corresponde a um momento de intensa movimentação política na França e está, como sabemos, intimamente ligado com o contexto das guerras de religião. É certo que, entre os anos de 1580 e 1590, houve uma intensificação dos conflitos que assolavam o território francês, no qual a guerra civil travada entre católicos e protestantes alcançava seu estágio mais violento. Juntamente com o agravamento dos conflitos, a participação ativa de Montaigne na vida pública exercendo o cargo de prefeito de Bordeaux, bem como a intensificação das discussões em torno das ações políticas suscitadas principalmente por Maquiavel, levaram nosso autor a redigir o ensaio em questão. Em outras palavras, Do útil e do honesto é um texto que está em perfeito diálogo com seu tempo, seja na relação que estabelece com o ideário político que as discussões que lhe eram contemporâneas construíam, seja em termos históricos, onde a cada dia a prática política que os governantes realizavam colocava em xeque os preceitos morais. Como exemplo deste dialogismo com as produções contemporâneas, podemos apontar brevemente duas grandes correntes que estabelecem alguma relação com o pensamento político de Montaigne, a saber, a influência do estoicismo imperial, revivido nos tempos de nosso autor pelos trabalhos dos ditos neo-estoicos, no termo cunhado por Leontine Zanta ${ }^{4}$, tendo como uma das principais influências Sêneca, Cícero e, em sua contemporaneidade, Justus Lipsius. Por outro lado, pode ser considerada uma importante

\footnotetext{
${ }^{3}$ Esta é a proposta apresentada por Pierre Villey, que credita aos treze ensaios do terceiro livro a data composta entre o final de 1585 e o início de 1588. C.f.: MONTAIGNE 2001, Livro III, p. 3.

${ }^{4}$ C.f.: ZANTA 1914.
} 
influência para Montaigne os teóricos da razão de Estado, alinhados principalmente pelas ideias dos realistas italianos, tendo como expoente máximo desta linha de pensamento Maquiavel.

Como claro exemplo desta ligação existente entre o pensamento de Montaigne e os desenvolvimentos teóricos de sua época, é possível apontar que nosso autor abre cada um dos três livros de seus Ensaios com claras referências à Maquiavel, como nos diz Nakan:

Cada um dos três livros dos Ensaios é introduzido por um capítulo com ressonância maquiaveliana: Por diversos meios chega-se ao mesmo fim (I, 1), Sobre a inconstância de nossas ações (II, 2), Do útil e do honesto (III, 1). E isto não é certamente sem razão. Tanto sob o plano filosófico, quanto sob o plano político, a visão fascinante de um universo complexo, dominado pelo acaso, imprevisível, em sua "branloire perenne", como dirá Montaigne, tais como são todas as ações humanas, a evidência da imortalidade na política e, contudo o poder da "virtù" do homem de exceção que sabe ter em suas mãos seja seu próprio devir, seja aquele dos outros: todas estas visões, sutis, originais e fortes não poderiam ter outro papel além daquele de cortar a imaginação de Montaigne, o seduzindo (NAKAN 1984, p. 246).

É certo, portanto, que o trabalho de Maquiavel exerceu grande influência sobre os pensadores políticos franceses, entre eles o próprio Montaigne. No entanto, as interpretações a respeito do pensamento do filósofo florentino são divergentes entre os críticos franceses e nosso autor. Montaigne reprova as conclusões as quais chega Maquiavel, mas, ao contrário de seus contemporâneos, não descarta totalmente seu pensamento. Parece-nos que Montaigne apreende bem a lição do pensador italiano ao admitir que existe, nas palavras de Villey, um "antagonismo profundo entre os preceitos da virtude e as exigências próprias da política” (VILLEY 1976, p. 373). Montaigne admite, portan- 
to, ideias que correspondem ao que chamamos de realismo político, afinal, o mundo das ações públicas não deveria mais ser compreendido enquanto uma esfera una e plenamente preenchida de virtudes, tal qual era idealizada na antiguidade. Montaigne percebeu bem que a realidade política contemporânea a ele não mais poderia limitar-se a pensar que, ao menos no plano teórico, todas as ações políticas deveriam ser necessariamente imbuídas dos mais altos valores morais. Não era isso o que acontecia em seu tempo, muito menos em um país prostrado pelos conflitos religiosos. Assim, como nos diz Villey:

Montaigne também criticou Maquiavel, mas não caiu no erro comum de seus contemporâneos. Ele reconheceu que o mundo dos fatos políticos não era submetido às nossas concepções morais; que é preciso lhe estudar, lhe observar para poder falar com certeza a respeito, e que em nenhum caso devemos substituir as realidades vivas por nossas ideias a priori. Ele constatou que o mal tinha um lugar importante no mundo e que querer o banir não passava de uma quimera. A política, que visa não a agir moralmente, mas a triunfar, deve contar com ele [mal], e deve fazer uso inclusive, em algumas ocasiões. É preciso que se saiba trair e enganar: o interesse do país exige isso (VILLEY 1976, p. 372).

O que está realmente em jogo, na discussão apresentada por Montaigne, não é, portanto, uma crítica ao pensamento de Maquiavel propriamente dito, mas sim uma crítica à intepretação reducionista, feita por seus contemporâneos, das teorias do autor florentino. Montaigne recusa os resultados apresentados pelos filósofos franceses que limitaram o pensamento de Maquiavel somente à prática desregrada de ações desonestas em prol da manutenção do Estado. Aliás, é preciso dizer que Montaigne se mantém contrário aos defensores da razão de Estado. É claro que nosso autor reconhece grandes ensinamentos no trabalho 
de Maquiavel, mas recusa quase que completamente a recepção comum deste pensamento no território francês. A crítica "maquiavelista", por assim dizer, não se dirige, portanto, ao próprio Maquiavel, mas sim à corrente "antimaquiavelista" existente na França ${ }^{5}$ neste período.

Contudo, se Montaigne admite, ao menos em parte, os preceitos de Maquiavel, ele ainda está muito distante de ser considerado um puro e simples pensador do realismo político. Há uma outra esfera cotejada por nosso autor que procura, como veremos a seguir, aproximar novamente as categorias de utilidade e honestidade, distanciadas em seu tempo. Mas, como veremos, esta aproximação será feita, no pensamento de Montaigne, com base principalmente nos ensinamentos da moral estoica, mais propriamente fundamentada nos ensinamentos de Cícero, uma das mais bem conservadas fontes acerca da moral estoica. É como se, maquiavelicamente, Montaigne reaproximasse o útil do honesto, preceitos da virtude estoica, como veremos, ora aproximando-se de tais conceitos, ora afastando-se em benefício dos defensores da razão de Estado. Assim, temos a construção de um pensamento político que está em plena conexão com seu tempo e seus interlocutores sem, contudo, perder de vista a linha profundamente erudita e conhecedora dos escritos antigos, tão cara a Montaigne. Deste modo, Do útil e do honesto configura-se, assim, como um texto escorregadio e de difícil compreensão. Seus meandros

\footnotetext{
${ }^{5} \mathrm{O}$ forte aumento do número de conselheiros italianos na corte de Catherine de Médicis aliado à uma imagem desgastada da economia e organização social da cidade de Florença, fruto de seu incipiente capitalismo, fez com que um movimento anti-maquiavelista se instaurasse na França. Há, na França do XVI um ideário político contrário às ideias de Maquiavel, movimento de resistência ao pensamento italiano e aos seus conselheiros, acusados de usurpar o poder popular e a proximidade do povo com seu soberano. Desta forma, tanto Maquiavel, quanto os conselheiros da corte de Catherine, L'italienne, são mal vistos seja por filósofos, seja pelo próprio povo francês.
} 
nos impedem de estabelecer qualquer tipo de enquadramento do pensamento de Montaigne em qualquer que seja a corrente filosófica pretendida, pois, como sabemos, o filósofo não deve ser lido nem como maquiaveliano, nem como estoico, mas sim como um pensador capaz de trilhar sua própria linha de argumentação com base na sólida análise do $E u$, dos casos particulares, dos exempla oferecidos pela história. Por fim, em termos políticos, toda a tentativa de generalização do pensador francês mostra-se ineficaz. É preciso observar cada caso individualmente, sempre com a mesma moderação e prudência já indicada pelos antigos estoicos, os quais Montaigne sempre admirou. Assim, qualquer esforço de estabelecer um único conjunto de regras e preceitos capazes de guiar o príncipe em sua conduta mostra-se insuficiente.

\section{OS ESTOICOS, GícERO E A MORAL ELEVADA}

É inegável a influência do pensamento estoico nos escritos de Montaigne, seja em sua afinidade temática com os filósofos estoicos, sobretudo do período imperial, seja no posicionamento moral que muitas vezes é tomado por nosso autor. No que diz respeito exclusivamente ao ensaio Do útil e do honesto, é patente o diálogo estabelecido entre Montaigne e a filosofia estoica, sobretudo com Cícero. A própria discussão a respeito do útil ou do honesto remete diretamente ao De Officiis de Cícero, livro que procurou completar a obra deixada pelo antigo estoico Panécio ${ }^{6}$, elu-

\footnotetext{
${ }^{6}$ Como nos diz Angélica Chiapeta, "A obra que Cícero seguiu de perto foi o famoso tratado Sobre o Dever (Peri toû kathékontos) de Panécio, o aristocrata ródio que viveu de aproximadamente 180 a 109 a.c" Cícero, M. T. Dos Deveres / Cícero; [tradução e introdução do latim de Angélica Chiapeta] Martins Fontes, São Paulo: 1999. Estamos, portanto, diante de uma interpreCont.
} 
cidando os pontos que lhe faltavam e solucionando alguns de seus conflitos. Já no proêmio do ensaio em questão, Montaigne nos remete para a existência da ideia de utilidade em tudo o que existe no cosmos, inclusive na própria noção de inutilidade, ideia que está plenamente de acordo com a concepção estoica providencialista ${ }^{7}$. Diz Montaigne: "Nosso edifício, tanto público quanto privado, é cheio de imperfeição. Mas não há nada inútil na natureza; nem mesmo a inutilidade; neste universo não se intrometeu coisa alguma que nele não tenha lugar oportuno" (MONTAIGNE 2001, p. 5-6; MONTAIGNE 2004, p. 790) $)^{8}$.

No entanto, veremos que, tal aceitação da ideia generalizada de utilidade não deve ser compreendida sob a óptica restrita da filosofia estoica, isso porque Montaigne admite que não é possível encontrarmos um completo espelhamento entre a noção própria de utilidade e as noções de honesto e virtuoso. Montaigne reconhece a utilidade do mundo, mas não seu completo imbricamento com o honesto, afinal, devemos nos lembrar que Montaigne aceita situações que são úteis, mas não virtuosas do ponto de vista moral, configurando um afastamento da ética estoica professada, por exemplo, por Cícero.

É, portanto, evidente que Montaigne não está plenamente convencido de que exista uma ordem providencial

tação da moral estoica imperial, que apresenta algumas mudanças em relação ao período grego, com Zenão.

${ }^{7}$ Sobre os fragmentos estoicos que serão utilizados neste artigo, consultar: Long, A. A. \& Sedley, D. N. Les philosophes hellénistiques. Vol. II. Les Stoïciens. Ed. GF Flamarion, Paris: 2001. Tal texto será, daqui em diante, identificado pela sigla L\&S, seguido do fragmento citado. Para mais informações sobre o providencialismo estoico, c.f. L\&S 55.

${ }^{8}$ Para facilitar o trabalho do leitor, incluo as referências à obra de Montaigne em duas versões. A primeira, na edição traduzida para o português no ano de 2001. Em seguida, a edição francesa comentada por Villey, do ano de 2004. 
no universo capaz de garantir que todas as ações honestas sejam necessariamente úteis, como se pode inferir do pensamento estoico. Afinal, o mundo contemporâneo a Montaigne não se apresenta mais como o mundo antigo, no qual ainda seria possível pensar na existência de uma força ordenadora principal, de uma physis ordenadora. Pois, lembrando propriamente a filosofia estoica:

se todas as coisas, sem exceção, são produzidas pelo imanente princípio divino que é lógos, inteligência e razão, tudo é rigorosa e profundamente racional, tudo é como deve ser e como é bom que seja, e o conjunto de todas as coisas é perfeito: não há obstáculo ontológico à ação do artífice imanente, pois a própria matéria é o veículo de Deus, e assim tudo o que existe tem o seu significado exato e é feito do melhor modo possível; o todo é em si perfeito: as coisas individuais, mesmo sendo consideradas imperfeitas em si, têm a sua perfeição no conjunto do todo (REALE 2001, p. 57).

É, por exemplo, o que nos diz Arístocles a respeito da conflagração universal $^{9}$, ao nos lembrar que o entrelaçamento do mundo é destino, ciência, verdade, lei infringível e inevitável dos seres e que, por este entrelaçamento, todas as coisas do mundo "são superiormente bem administradas, como em uma sociedade política perfeitamente organizada”. Tal interpretação, também possui respaldo nos escritos de Cícero, como bem lembrado por Valente:

para o antigo estoicismo, o fim, o soberano bem, o belo, a virtude, o honesto era um só: a conformidade com o logos. Como esta conformidade se apreendia na tendência do vivente para acomodar-se à natureza e conservar o ser, tudo isso devia considerar-se também útil. Tal é, com pequenas variações, o ponto de vista de Cícero, quando afirma que tudo o que é moral é útil (VALENTE 1984, p. 78-79).

\footnotetext{
${ }^{9} \mathrm{~L} \& S 46 \mathrm{G}$
} 
Para Cícero não existe conflito entre o útil e o honesto, visto que a virtude e a honestidade devem ser compreendidas enquanto adequação do ser à sua natureza, tanto particular, quanto à natureza compreendida enquanto racionalidade ordenadora do cosmos. Diz Valente, a respeito da concepção do autor romano, que os conceitos morais, a beleza, a utilidade e a felicidade são deduzidos da conformidade com a natureza; a orientação para a virtude é a tendência natural da lógica humana (VALENTE 1984, p. 93). A natureza humana, que difere dos demais animais ${ }^{10}$, tem como característica própria a participação na razão. É esta participação que nos permite inferir os deveres inerentes a cada um. Participar da razão é, para os homens, ajustar-se oportunamente à sua própria natureza. No mesmo parágrafo, o autor ainda afirma que "Todas as coisas justas são decorosas; as injustas, como as torpes, são indecorosas" (CÍ́CERO 1999, p. 48). A honestidade é, portanto, decorosa à natureza humana e, continua Valente

não é certamente qualquer instinto que proporcionará ao homem sua utilidade específica. $\mathrm{O}$ que impele ao mal, ao abuso da força, a intemperança, em última instância, só depende da natureza animal; mas o homem enganar-se-ia redondamente se colocasse aí a sua utilidade. Pelo contrário, se ele se concentra em si mesmo, descobre que ocupa um lugar bem à parte entre todos os seres. Utilíssimo é, pois, para ele o que lhe tolhe a derrocada própria e lhe firma a superioridade no mundo: a beleza moral (VALENTE 1984, p. 91).

Igualmente é o que se lê nos trechos do De Officiis: "Decoro é o que convém à excelência do homem naquilo

\footnotetext{
${ }^{10}$ Diz Cícero sobre a diferença entre a natureza humana e dos demais animais: "É pertinente a toda investigação do dever ter em mira o quanto a natureza do homem ultrapassa a dos animais domésticos e das feras. Nada sentem os animais a não ser o prazer; para o qual são arrastados com o máximo ímpeto; o espírito do homem, ao contrário, é nutrido pelo aprendizado e pelo pensamento" (CÍCERO 1999, p. 52).
} 
em que a sua natureza difere dos outros animais" (CÍCERO 1999, p. 48), “O nosso papel, a própria natureza no-lo impôs com tal magnificência que superamos todos os seres vivos" (CÍCERO 1999, p. 49), e ainda no seguinte trecho "Um dos personagens com que nos revestiu a natureza é comum a todos, pelo fato de que todos participamos da razão e da sua excelência. Por ela nos avantajamos dos animais, dela flui tudo o que é honesto e decoroso, a ela pedimos a norma para estabelecer nossa obrigação" (CÍCERO 1999, p. 53).

Alcançar a beleza moral seria, então, alcançar a plena adequação do ser à sua natureza. Diz Cícero:

Os homens, quando dissociam a utilidade da honestidade, pervertem os fundamentos da natureza. Todos, com efeito, buscamos a utilidade, somos atraídos por ela e não podemos agir de outro modo. Quem evitaria coisas úteis? Ou antes, quem não as perseguiria com o maior empenho? Mas como só podemos encontrar as coisas úteis na esfera do mérito, da conveniência e da honestidade, colocamos esta esfera no primeiro e mais elevado plano (CÍCERO 1999, p. 50).

A felicidade suprema, a eudaimonia ( $\varepsilon u ́ \delta \alpha \iota \mu$ oví $\alpha$ ), o fim último de nossas ações, deve ser, consequentemente, as ações honestas e virtuosas, uma vez que estas estão em plena harmonia com nossa natureza racional, de entes que não se entregam às paixões e instintos animais ${ }^{11}$. Diz Cícero: "A verdadeira e sábia grandeza de alma julga honesto aquilo que a natureza persegue de perto e que reside, não na glória, mas nos atos" (CíCERO 1999, p. 34).

Mas como guiar tais atos? Como resolver os aparentes conflitos existentes entre o útil e o honesto? Como o ho-

${ }^{11}$ Neste sentido, a volúpia não deve ser considerada. 
mem que não é sábio poderia se portar frente ao conflito? Cícero escreve o De Officiis como uma espécie de manual ético para os ditos homens de bem, já que os sábios seriam aptos a agir visando o fim último e conforme a natureza, sem dúvidas quanto aos possíveis conflitos entre utilidade e honestidade. O autor romano deixou um tratado acerca da ética prática para o homem bom que busca seu progresso moral. O que Cícero ensina é como tomar decisões morais, como analisar diferentes caminhos possíveis de ação. Desta forma, é no plano do katékon ${ }^{12}$, das ações preferíveis, que a argumentação ciceroniana será desenvolvida. As katékonta (ou atos convenientes) pautam-se por quatro virtudes essenciais para Cícero, são elas: 1. cognitio, 2. designada pelo autor pelos termos iustitia, beneficentia e liberalitas, 3 . magnitudo animi e, por fim, o 4. decorum. Destas quatro virtudes, o autor romano nos indica seus respectivos deveres.

O texto Do útil e do honesto, de Montaigne, estabelece clara relação com os pontos enumerados por Cícero. $\mathrm{O}$ autor francês admite a importância das quatro virtudes principais apontadas no De Officiis, reconhecendo que é somente no plano do katékon (dever), da moral média, que é possível estabelecer algum debate na política de seu tem-

\footnotetext{
${ }^{12}$ Para os antigos estoicos, existe uma divisão entre o que é chamado Katórthoma, ação reta e executada pelo sábio, e o dever, os ditos kathékon (ações virtuosas executadas por homens comuns). Cícero trata deste segundo tipo de ação, pois sua preocupação fundamental é a ação do homem que não é sábio, que não alcançou plenamente sua natureza. Assim, em linhas gerais, quem possui a virtude, ou seja, o lógos harmonizado de modo perfeito, só pode realizar ações perfeitas (katórthoma). Este é o sábio. Para todos os outros, os estoicos desenvolveram a ideia de dever, de ações preferíveis (Kathékon). Afinal, "As ações humanas não podem ser divididas com uma nítida distinção entre ações retas e virtuosas e ações que lhe são contrárias, isto é, ações viciosas ou erros" (REALE 2011, p. 93). Portanto, foi preciso estabelecer regras, preceitos que fossem capazes de guiar o homem comum em busca da virtude, classificando ações que sejam mais ou menos próximas de uma justificação racional, sendo, consequentemente, mais convenientes. É, por fim, destas ações preferíveis, convenientes, que Cícero tratara no De Officiiis.
} 
po. No que diz respeito exclusivamente a iustitia e a liberalitas, ponto crucial do diálogo entre Cícero e o texto de Montaigne, o autor romano nos indicará quais os deveres relativos a tal virtude e, dentre eles, explicitará a noção de fides. Montaigne, baseado justamente neste ponto do De Officiis, desenvolverá seu pensamento político, pautado pela noção de fides, que merece especial atenção de nossa parte. Para Cícero, fides corresponde a basicamente três significados que se entrelaçam. Diz Valente,

Primeiro, é a palavra dada, promessa, juramento, contrato de compra e venda, pacto público; e por isso é que se devem respeitar os acordos feitos com os inimigos (De Officiis, I, 39), Depois, é a lealdade a essa palavra, com exclusão da fraude e do fingimento, e a obrigação de respeitar as cláusulas do compromisso e a vontade de o executar fielmente, razão por que os acordos das pessoas de bem gozam de um caráter sagrado e da sanção autorizada da lei (De Officiis, III, 61). Finalmente, o cumprimento leal da palavra dada gera a confiança dos outros e da multidão. (De Officiis, II, 31). Essas três espécies de fides convergem no vínculo social que une os indivíduos entre si, os cidadãos ao Estado e um Estado aos outros (VALENTE 1984, p. 184).

Montaigne parece aceitar, em linhas gerais, aquilo o que o autor romano diz mas, no entanto, levará a noção de fides às últimas consequências, elevando ao máximo suas implicações no combate aos defensores da razão de estado. A fides para Montaigne, assim como para Cícero, adquire valor e papel de suma importância na manutenção da ordem social, transformando-se em instrumento para a conservação dos elos sociais e do próprio Estado. No entanto, se para Cícero a fides é o sustentáculo da justiça, para Montaigne ela terá outro significado. Como já sabemos, tanto os pensadores estoicos, como Cícero, acreditavam que, entre utilidade e honestidade, haveria uma ligação intrínseca, um perfeito espelhamento. Já para Montaigne, o 
mesmo não se dá da mesma forma.

Ora, Montaigne não pode admitir esta coincidência entre o útil e o honesto, não pode compreender a natureza de forma perfeita, providencialista e em plena harmonia com o lógos. Pois, devemos bem lembrar, Montaigne afirma que "Há vícios legítimos, assim como há muitas ações boas ou justificáveis, ilegítimas" (MONTAIGNE 2001, p. 14; MONTAIGNE 2004, p. 796) e todo aquele que busca suprimir a característica viciosa do homem e do mundo, os compreende mal. Diz Montaigne a respeito da fábula de Esopo, na qual um burro tenta passar-se por cachorro: "Não quero privar de sua posição o logro; isso seria compreender mal o mundo; sei que amiúde ele tem servido proveitosamente, e que mantém e alimenta a maioria das ocupações dos homens" (MONTAIGNE 2001, p. 13-14; MONTAIGNE 2004, p. 795). Montaigne aceita as imperfeições mundanas, aceita e reconhece os vícios como partes constituintes de nossa natureza, assim como a virtude. Por este motivo, Montaigne não pode admitir a katórthoma (perfectum officium), ação perfeita. Afinal, não estamos lidando com sábios, mas com simples homens. É, por conseguinte, das katékonta (officium) que nosso autor tratará. Eis aqui mais um dos pontos de ruptura com o pensamento dos estoicos, afinal, reconhecer tais defeitos equivale a reconhecer que não estamos mais sob o jugo do lógos perfeito, do lógos estoico, por assim dizer. Diz nosso autor:

Nosso ser está cimentado de qualidades doentias, a ambição, o ciúme, a inveja, a vingança, a superstição, o desespero alojam-se em nós com uma dominação tão natural que sua imagem é reconhecida também nos animais; e até mesmo a crueldade, vício tão desnaturado; pois, em meio à compaixão, sentimos interiormente uma certa pitada agridoce de voluptuosidade maligna ao ver outrem sofrer; e as crianças sentem isso (MONTAIGNE 2001, p. 6; MONTAIGNE 
2004, p. 791).

Para Montaigne, portanto, existe a possibilidade de admitirmos algo que seja apenas útil, mas não honesto. Assim, na questão política propriamente dita, Montaigne afirma que "em todo governo há serviços necessários, não apenas abjetos como também viciosos: neles os vícios encontram seu lugar e são empregados na costura de nossa ligação, como os venenos na conservação de nossa saúde" (MONTAIGNE 2001, p. 6; MONTAIGNE 2004, p. 791). Há, por conseguinte, ações políticas que não sendo virtuosas e honestas, são admissíveis do ponto de vista da utilidade comum. Se, como diz o autor, "O bem público requer que se atraiçoe e que se minta e que se massacre" (MONTAIGNE 2001, p. 6; MONTAIGNE 2004, p. 791), e tais coisas são tidas como úteis, então estamos em um plano referencial completamente diverso do pregado pelo estoicismo.

Dada a impossibilidade, para Montaigne, do imbricamento entre útil e honesto - ou pelo menos de seu imbricamento necessário - a própria noção de justiça também sofrerá alterações se comparada à sua semântica estoica. A noção de justiça em Montaigne não tem a mesma implicação que para Cícero e sua garantia não mais pode ser sustentada por meio de uma natureza racional, de um lógos ordenador. No texto Do útil e do honesto, Montaigne desloca a ideia de justiça para outro lado. $\mathrm{O}$ autor francês faz com a fides aquilo o que Cícero faz com a justiça. Contra todos aqueles que veem na política somente o espaço do artifício e da utilidade, nosso autor invoca novamente os preceitos estoicos contra os maquiavelistas. Será por meio da oposição entre fides e perfídia que Montaigne estabelecerá o fundamento da política. 
O próprio texto Do útil e do honesto nos remete, a todo momento, para a questão da boa-fé, da palavra dada e de sua oposição à perfídia. Diz Villey:

Faça um teste: você verá seu ódio por todo engano e toda dissimulação. Mesmo por negociar as questões públicas, lhe é impossível de dissimular seu pensamento. Sob sua palavra, ele é escrupuloso a ponto de protestar violentamente contra os moralistas que permitem a anulação de uma promessa arrancada à força (VILLEY 1976, p. 441).

Montaigne, deste modo, parece levar às últimas consequências a ideia de fides. E, ao contrário de Cícero ${ }^{13}$, não admite contestar uma palavra dada nem quando tal palavra prejudica quem a ofereceu, nem quando foi dada a força ou sob manobra viciosa. A palavra dada adquire, para Montaigne, um valor praticamente sagrado. É por meio da fides que a sociedade une-se, que seu liame pode ser mantido. Na própria casuística apresentada pelo autor francês a questão da fides se apresenta de forma especial. A todo momento, no texto, Montaigne of erece exemplos negativos contra todos aqueles que se utilizaram da perfídia para alcançar seus objetivos, sendo eles legítimos ou não (sendo eles motivados pelo bem comum ou não). Para Montaigne, a perfídia é, na esmagadora maioria das vezes, improdutiva politicamente e só "pode ser justificável em um único caso: é-o somente quando empregada para punir e atraiçoar a perfídia" (MONTAIGNE 2001, p. 16; MONTAIGNE 2004, p. 797). É o que o autor diz no caso específico do príncipe que trai o magistrado traidor.

A fides, ao contrário, mostra-se como um sustentáculo

\footnotetext{
${ }^{13}$ Diz Cícero: "Deve-se sempre preservar os pactos e compromissos que, como dizem os pretores, não foram estabelecidos pela força nem pelo mau dolo." (CÍCERO 1999, p. 169). Ver também, no De Officiis, os livros I, capítulo 32, I.40, III.107 e III.110-113.
} 
mais eficaz, seguro e virtuoso, realmente capaz de unir os homens. Portanto, ao retomar o conceito de fides, Montaigne apresenta uma nova saída para a conservação do Estado. A fides tem maior serventia que a perfídia, pois é capaz de manter-se no tempo e garantir efetivamente o poder. O conceito de fides será, como veremos a seguir, o elo essencial da sociedade em tempos de exceção, e não mais os argumentos apresentados pelos defensores da razão de estado.

\section{MAQUIAVEL E A RAZÃo DE ESTADO}

Como já dissemos anteriormente, o pensamento de Maquiavel exerceu grande influência na reflexão política contemporânea a Montaigne, possuindo, inclusive, grande espaço no universo teórico do autor francês ${ }^{14}$. No entanto, a aproximação com a filosofia de Maquiavel deve ser tomada com precaução. Pois, mesmo que Montaigne aceite o realismo político de Maquiavel, o autor francês não teria sido somente influenciado por ele, nem tão pouco teria levado seu pensamento às últimas consequências, de forma cega e doutrinária. Diz Tétel: "Montaigne é raramente categórico ou assume univocamente uma posição" (TÉTE 1992, p. 79). E ainda, mais adiante:

De fato, Montaigne considera Maquiavel por meio de uma perspectiva muito relativa. Ele sugere que o autor dos Discorsi procurara a estabilidade no personagem do príncipe, mas teria sobretudo observado uma falta de estabilidade, neste personagem e na História. Em outros termos, Montaigne não considera Maquiavel ou seus críticos de maneira absoluta e literal, sobretudo no que concerne a significa-

\footnotetext{
${ }^{14}$ É certo que Montaigne cita Maquiavel poucas vezes (p. ex. II.17 e II.34), mas a influência de seu pensamento é inegável em torno dos três tomos dos Ensaios.
} 
ção do príncipe mesmo (TÉTEL 1992, p. 79).

É certo que Montaigne não teve somente a influência do realismo político em suas obras. Há, além do estoicismo, como já apresentamos acima, a presença de inúmeros autores imbricados em seu pensamento. Montaigne viveu em uma época na qual as construções teóricas a respeito do governo e sua manutenção são expressivas. Assim, nosso autor leu Maquiavel (1469-1536), Jean Bodin (15301596), Platão e seus livros da República, Erasmo e muitos outros, sempre em busca de alguma solução que fosse capaz de resolver os problemas políticos, no entanto, em todas as teorias que lhe foram apresentadas havia falhas que não permitiam uma sustentação do poder de forma efetiva. É claro que Montaigne sempre se mostrou contrário a qualquer tipo de posição final e imutável que tivesse como pretensão estabelecer uma verdade única. Como sabemos, seu ceticismo e sua suspensão do juízo pirrônica nunca o permitiu encarar a obra filosófica como algo determinado em si mesmo, absoluto. Diz Friedrich: "Não se pode jamais perder de vista que Montaigne não quer ensinar a casualidade da condução, mas sim procura compreender a natureza mesma de nossa condição" (FRIEDRICH 1968, p. 201). Por isso, a posição política de Montaigne carrega também traços deste comportamento, tornando muito difícil sua análise e compreensão. O texto Do útil e do honesto é de tal forma escorregadio que qualquer desejo de atribuir-lhe um direcionamento único seria imediatamente confundido com a presunção de quem o fizesse. Deixemos claro, portanto, que este não é nosso objetivo.

As guerras de religião na França, aliadas ao novo modelo estrutural da sociedade e a fundação política dos grandes Estados, fez com que muitos autores do XVI bus- 
cassem fundamentar a origem do poder em seus mais diversos planos referenciais, sejam religiosos, utópicos, terrenos ou simplesmente, como o faz nosso autor, no plano dos costumes ${ }^{15}$. Precisamos lembrar, é verdade, que Montaigne é um autor que busca a compreensão da política com base em um estudo pormenorizado dos casos particulares, evitando todo o tipo de generalização desnecessária. Por isso o estudo dos casos particulares é tão importante e evidente no decorrer de toda a sua obra. Seus exempla são, do ponto de vista teórico, fundamentais para a compreensão do pensamento filosófico e político de Montaigne. Este é o caso, também, do ensaio que tratamos aqui, a saber, Do útil e do honesto (III, 1). É a própria natureza da política que impede generalizações, visto que existe uma dependência dos homens e de suas vontades à providência e à fortuna. Tal relação intrínseca entre a fortuna e as ações humanas é também tratada por Maquiavel, que lhe dá grande valor e importância.

As generalizações são, portanto, ineficazes para compreendermos a política. Pois, para Montaigne, desde suas origens mais longínquas, o sistema das leis, do direito e da política estão apoiados pelo costume, e não na ideia de um direito universal transcendente às comunidades. É o que diz Montaigne no seguinte trecho: "A justiça em si, natural e universal, está ordenada de forma diferente e mais nobre do que esta outra justiça especial, nacional, submetida às necessidades de nossas sociedades" (MONTAIGNE 2001, p. 14; MONTAIGNE 2004, p. 796). E completa, citando a

\footnotetext{
${ }^{15}$ Lembremos que Montaigne parece rejeitar a ideia comum de direito. Desta forma, as leis devem ser compreendidas enquanto fruto dos costumes, obtendo sua autoridade única e exclusivamente do fato de serem encaradas enquanto leis e obedecidas usualmente. (FRIEDRICH 1968, p. 198)
} 
célebre passagem de Cícero que diz: "Não possuímos um modelo sólido e exato do verdadeiro direito e da justiça perfeita; fazemos uso de sua sombra, de sua imagem"16. A negação da universalidade do direito e da justiça permitirá, assim, à Montaigne, entender estes princípios enquanto resultados de um conhecimento histórico, mutáveis e com valores que não podem ser caracterizados como eternos. É na negação da ideia de lei natural que Montaigne estabelecerá seu sistema. Este que está intimamente ligado com o desenvolvimento de um "humanismo experimental que, a princípio, funda na experiência histórica a elaboração do direito e permite a previsão das ações políticas" (NAKAM 1984, p. 240). Ao lermos o ensaio nesta chave, veremos que, como nos diz Friedrich, "a ideia de direito natural é para ele uma hipótese que introduz a identidade na diversidade e viola, assim, a estrutura essencial do homem." E, mais adiante, o comentador continua: "Para Montaigne, o direito se constitui inteiramente de princípios positivos concebidos historicamente e não por meio do desenvolvimento de uma ideia eternal” (FRIEDRICH 1968, p. 203).

O conhecimento dos costumes, da organização social à qual se pertence, e dos grandes e infinitos exemplos que a história nos forneceu é o que pode nos ajudar a driblar os infortúnios e adversidades do destino. A política deve ser feita, portanto, com prudência. Na qual, cada caso, isoladamente, deve ser observado de forma minuciosa para, somente depois, assumir alguma conduta.

Maquiavel, como sabemos, também considerou, em seus escritos, a política enquanto um campo de ação inconstante e submetido a rápidas e incessantes mudanças.

\footnotetext{
${ }^{16}$ C.f.: Cícero, De Officiis. III, XVII (CÍCERO 1999, p. 156).
} 
"Sua obra não é propriamente uma teoria geral do poder político, mas, antes de tudo, um discurso adequado à experiência imediata da realidade histórica das cidades italianas renascentistas agitadas pelos golpes de Estado [...]" (HANSEN 1996, p. 146). Era preciso, portanto, estabelecer uma arte política, transformando seu conteúdo em uma ciência capaz de preparar o homem para enfrentar as mutações da fortuna. O homem, ou no caso, o príncipe, deveria estar pronto para agir e combater qualquer adversidade que lhe fosse apresentada. A postura maquiaveliana é, em suma, combativa frente à fortuna. $\mathrm{O}$ objetivo principal de Maquiavel seria, portanto, oferecer um conjunto de preceitos que seriam capazes de permitir a quem o praticasse, alcançar o sucesso em suas ações. A política estaria, a partir de então, ligada não somente à utilidade, mas sim à sua eficácia. Este é, também, o ponto de união de Maquiavel e a corrente da razão de Estado. Pois, como nos diz Hansen, a "razão de estado supõe o príncipe como artesão, e o Estado, como matéria do poder” (HANSEN 1996, p. 141). Assim, "a expressão razão de Estado é usada para significar o imperativo em nome do qual, alegando o interesse público, o poder absoluto transgride o direito. Via de regra, a ação é acompanhada de três alegações ou condições: as medidas excepcionais são necessárias; um fim superior justifica os meios empregados; o segredo deve ser mantido" (HANSEN 1996, p. 136).

Ora, se Maquiavel e os críticos da razão de Estado estão preocupados com a eficácia da ação do príncipe, na qual se reflete a necessidade primeira de manutenção do Estado, Montaigne não parece estar muito distante destas preocupações. Em vista das guerras que assolam a França e do risco iminente de uma ocupação espanhola de seu terri- 
tório, a manutenção do poder e da estrutura governamental do Estado francês se mostra imprescindível. É com base nesta manutenção do poder, tão reivindicada no XVI, que Montaigne inverterá radicalmente a posição de todos aqueles que acreditam que a perfídia pode exercer o papel de instrumento essencial para a garantia do poder. É preciso, para Montaigne, manter a prudência e a lucidez ao admitir as posturas "maquiavélicas”. A ação política deve ser tomada, mas seguindo, é claro, as recomendações de moderação dos antigos estoicos ${ }^{17}$. Primeiramente, lembremos do autor italiano: "Maquiavel toma a ação por sua eficácia e de uma estrutura política: Ciascuno principe debbe desiderare di essere tenuto pietoso e non crudele: nondimando debbe avvertire di non usare male questa pietà. De seu lado, Montaigne rejeita os extremos e opta pela lucidez" (TÉTEL 1992, p. 88) ${ }^{18}$.

Montaigne nos mostrará, nos mesmos termos de Maquiavel, que a eficácia da perfídia é contraproducente. A longo prazo, dirá o autor francês, a perfídia se revelará ineficaz para a manutenção do Estado e da organização política, pois a autoridade do poder parece estar fundada nos costumes e crenças ${ }^{19}$. Montaigne, ao contrário de Maquiavel, compreenderá, como nos diz Cardoso, a

sociedade política como uma comunidade de crenças positivas, originadas da acomodação de forças, interesses e partidos historicamente constituídos, e sustentados e travejados pelo costume, que mantém a crença - fundante - na sua naturalidade. Assim, toda a

\footnotetext{
${ }^{17}$ Sobre a ação política moderada e cautelosa, diz Montaigne: "No entanto, até mesmo aqueles que se engajarem totalmente podem-no com tal ordem e moderação que a tempestade deverá passar-lhes sobre a cabeça sem atingi-los" (MONTAIGNE 2001, p. 10; MONTAIGNE 2004, p. 793).

${ }^{18}$ C.f. também (MAQUIAVEL 2001, p. 79).

${ }^{19}$ C.f.: (FRIEDRICH 1968, p. 198).
} 
autoridade legítima está umbilicalmente atada a essas crenças comuns, das quais as leis estabelecidas são a expressão jurídica, e o soberano, o instrumento político (CARDOSO 1996, p. 190).

Eis aí novamente o conceito de fides reinserido no realismo político de Montaigne. Estas crenças, bases sob as quais as leis se desenvolvem e a comunidade política se estrutura, são aquilo que mantém, de forma eficaz, "as costuras de nossa ligação". A chave para a compreensão da manutenção do Estado em tempos de exceção não está em uma saída universal, em uma moral universal transcendente e eterna, como vista no estoicismo. Não está também na saída pragmática da perfídia maquiavélica, pois esta se mostra ineficaz a longo prazo. Mas, como nos diz Friedrich, "É na lealdade prática para com os costumes de seu país, ao contrário, que se encontra a condição de uma existência social e pessoal" (FRIEDRICH 1968, p. 208). A saída apresentada por Montaigne é, portanto, diferente dos críticos do maquiavelismo francês. Montaigne retira a questão da razão de Estado de seu universo estritamente moral, aplicando-lhe outro tratamento. Diz Friedrich: "Montaigne, como vimos, está longe de uma indignação moral. A sinceridade lhe parece simplesmente a tática mais propícia. Sua resposta não deixa o terreno pragmático do princípio maquiaveliano. Não seria uma refutação de Maquiavel” (FRIEDRICH 1968, p. 198).

Assim,

Aquilo que convém ao Estado, à sociedade, à família e aos costumes não se define por noções de justo ou injusto, mas de ordem e desordem. E ordem, neste caso, não tem outro papel além de ser uma regra do jogo, um expediente em uma existência onde tudo se revelou oportuno, - uma contingência organizada. Indiferente aos valores, é ela que conserva a vida (FRIEDRICH 1968, p. 207). 
Em suma, longe de chegarmos a uma conclusão, encontramos no texto de Montaigne matéria suficiente para pensarmos a política em todos os seus aspectos. Seja nas constituições de seus sistemas jurídicos, seja na constituição da própria comunidade política e seus modos de governo. Nas palavras do autor: "Soneguemos às índoles maldosas, sanguinárias e traiçoeiras esse pretexto calculista; deixemos de lado essa justiça enorme e fora de si e atenhamo-nos às imitações mais humanas" (MONTAIGNE 2001, p. 25; MONTAIGNE 2004, p. 803). Isto é, mantenhamo-nos no caminho do entendimento dos costumes, das crenças. Fundemos nosso direito e nosso Estado de forma terrena, sem idealizações quanto aos homens. O mundo político, assim como todas as instituições humanas, é também reflexo dos próprios homens. A unidade absoluta, a moral universal não existe. A justiça não pode ser compreendida enquanto entidade absoluta, pois "Os princípios do Direito são normativos, não por sua legitimidade, mas pela autoridade de sua existência" (FRIEDRICH 1968, p. 204). E, como podemos ler nos Ensaios, as leis "não são obedecidas agora porque são justas (segundo a justiça universal e natural como diz o ensaio III, 1) mas - diferença essencial - porque se acredita que o sejam” (CARDOSO 1996, p. 191).

A mudança de terreno que Montaigne opera é aqui visível. Mesmo considerando que a política pode admitir a perfídia, a mentira e, por vezes, a crueldade, tais artifícios não são suficientes para a manutenção do Estado. Ao contrário, seu uso frequente e injustificado, como pretendem os defensores da razão de Estado e os ensinamentos de Maquiavel, enfraquecem cada vez mais os elos que mantém os homens unidos. Pois, se a sociedade, o governo, o corpo 
político são - como já vimos - fundamentados em crenças e costumes, na fides, o uso amplo e desmedido da perfídia produzirá resultados nefastos para a conservação e bom funcionamento do Estado. Há, no pensamento de Montaigne, por conseguinte, a universalização da honestidade. É a honestidade, a boa fé, a fides que ocupará o lugar da justiça estoica. Lembremos o exemplo de Tibério: "Mas a admissão da virtude não significa menos na boca de quem a detesta, porquanto a verdade arranca-a dele à força e, se não a quer acolher em si, pelo menos cobre-se com ela para enfeitar-se" (MONTAIGNE 2001, p. 5; MONTAIGNE 2004, p. 790). A perfídia existe, não é possível negar. Não estamos, no XVI, no mundo perfeito e providencialista dos estoicos. Montaigne sabe e conhece como poucos os meios políticos, mas o uso indiscriminado da mentira e da crueldade, sem arrependimento ou pesar da consciência, equivale ao fim do corpo político. Por isso, a perfídia é escusável $^{20}$, mas somente em situações raríssimas, absolutamente rarefeitas e, como se sabe, uma única vez no tempo. É o que diz o autor no seguinte trecho:

O príncipe, quando uma circunstância urgente ou algum tumultuoso e inopinado acontecimento, por necessidade de sua condição, obriga-o a faltar à sua palavra e à sua promessa, ou de qualquer outro modo lança-o fora de seu dever, deve atribuir essa necessidade a um golpe da vara divina. Vício não é, pois ele deixou sua razão por uma razão mais geral e poderoso; porém certamente é uma infelicidade. De maneira que, a alguém que me perguntava: "Que remédio? - nenhum remédio, respondi; se ele ficou realmente coagido entre esses dois extremos ("sed videat ne quaeratur latebra perjurio"), tinha de agir assim; mas se o fez sem lamentar, se não lhe pe-

\footnotetext{
${ }^{20}$ No caso específico da perfídia do príncipe, quando usada contra um magistrado traidor. Ou, nas palavras de Montaigne, a perfídia "pode ser justificável em um caso: é-o somente quando empregada para punir e atraiçoar a perfídia" (MONTAIGNE 2001, p. 16; MONTAIGNE 2004, p. 797).
} 
sou fazê-lo, é sinal que a sua consciência está em maus termos (MONTAIGNE 2001, p. 12; MONTAIGNE 2004, p. 794).

Outro exemplo claro no texto de Montaigne está na seguinte passagem: "Esses são exemplos perigosos, raras e doentias exceções a nossas regras naturais. É preciso ceder a elas, mas com grande moderação e circunspecção; nenhum benefício privado merece que por ele façamos tal violência à nossa consciência; o público, sim, mas só quando for muito evidente e muito importante" (MONTAIGNE 2001, p. 12; MONTAIGNE 2004, p. 794). Nas palavras de Nakam, Montaigne poderia ser considerado, portanto, como um maquiaveliano do bem, um realista moral: "É a justiça, o respeito dos direitos da natureza e da consciência que se revelaram ser, muito mais que honestos, úteis. A justiça humana de Epaminondas porta mais força persuasiva que a justiça enorme de César na Farsália” (NAKAM 1984, p. 259).

A força do pacto, se assim podemos dizer, reside na universalidade da honestidade e no respeito que os homens têm à fides. Não se obedece às leis por serem justas, mas pelo único e exclusivo motivo de serem leis. É no pacto, na firmeza da palavra dada que a sociedade pode se manter. Afinal, nenhum governo ou poder que se pretende soberano poderia se manter, por longo tempo, sendo exclusivamente fundado na mentira e na tirania. $\mathrm{O}$ corpo político que é regido pela mentira, gera desconfiança, torna-se ilegítimo e tirânico. As leis, para Montaigne, na ausência da justiça universal (katórthoma), transformam-se no verdadeiro katékon estoico. E a profissão de lealdade deverá ser feita dever, ter sua bandeira erguida, ser buscada, a todo custo, pelo homem de bem que julgue o bem comum acima de seus interesses particulares. "Explicamos mal a honestidade 
e a beleza de uma ação por meio de sua utilidade; e concluímos mal ao estimar que todos estejam obrigados ela e que ela seja honesta para todos se for útil" (MONTAIGNE 2001, p. 25; MONTAIGNE 2004, p. 803).

Abstract: This paper proposes to analyze the first text of the third book of Montaigne's Essays, entitled "From the Helpful and the Honest," establishing a parallel between Montaigne' s ideas in the foreground, the constructions of stoic moralism, and with the precepts developed by Machiavelli. In this context, we want to show that in the political context of his time Montaigne affirms the idea of fides as an element capable of guaranteeing the maintenance and preservation of political institutions more effectively than the simple ethics of results professed by the defenders of reason of State. Montaigne is thus uniting both Stoic morality and the currents of thought of his time.

Keywords: Montaigne; Cicero; Fides; Stoic Moral.

\section{REFERÊNGIAS}

CARDOSO, S. "Uma fé, um rei, uma lei - A crise da razão política na França das guerras de religião". In: A crise da razão. Org. Adauto Novaes. São Paulo: Companhia das Letras, 1996.

CÍCERO, M. T. Dos Deveres / Cícero; [tradução e introdução do latim de Angélica Chiapeta]. São Paulo: Martins Fontes, 1999.

FRIEDRICH, H. Montaigne. Gallimard, Paris: 1968.

HANSEN, J. A. "Razão de estado". In: A crise da razão. Org. Adauto Novaes. São Paulo: Companhia das Letras, 1996.

MAQUIAVEL, N. O Príncipe. Tradução Maria Júlia Goldwasser. São Paulo: Martins Fontes, 2001. 
MONTAIGNE, M. Os Ensaios. São Paulo: Martins Fontes, 2001.

. Les Essais. Paris: Quadrige/PUF, 2004.

NAKAM, G. Les Essais de Montaigne: Miroir et Proces de leur Temps. Paris: Librairie A. - G. Nizet, 1984.

REALE, G. Estoicismo, Ceticismo e Ecletismo. São Paulo: Edições Loyola, 2011.

TÉTEL, M. Présences italiennes dans Les Essais de Montaigne. Paris: Honoré Champion, 1992.

VALENTE, M. S. J. A ética estoica em Cícero. Caxias do Sul, EDUSC, 1984.

VILLEY, P. Les Sources et L'Evolution des Essais de Montaigne. T. I. Otto Zeller \& Osnabrück, 1976.

ZANTA, L. La renaissance du stoïcisme au XVI siècle. Paris: Librarie Ancienne Honoré Champion, 1914. 